\title{
Preliminary evaluation of grain yield components in hexaploid tritordeum
}

\author{
Ronald José Barth Pinto*1; Juan Bautista Alvarez² and Luis Miguel Martín ${ }^{2}$ \\ ${ }^{1}$ Departamento de Agronomia, Universidade Estadual de Maringá, Av. Colombo 5790, CEP 87020-900, Maringá, PR, \\ Brazil; ${ }^{2}$ Departamento de Genética, ETSIAM, Universidad de Córdoba, Avda. Menendez Pidal S/N, apartado 3048, 14080 - \\ Córdoba, Espanha. ("Corresponding author. E-mail: pinque@wnet.com.br)
}

\begin{abstract}
Chromosome duplication of Hordeum chilense and Triticum turgidum conv. durum hybrids created a new cereal with favorable characteristics for planting: the hexaploid tritordeum (X Tritordeum Ascherson et Graebner). A field experiment with three replications was carried out in Cordoba, Spain, to obtain more information on the potential yield of tritordeum for grain yield and its components. The performance of two advanced tritordeums was compared with the yield of two commercial wheat varieties, two durum wheats and four triticales. Results showed that tritordeum has a great potential for the development of highly productive varieties, especially because it is a new and rarely bred species.
\end{abstract}

KEY WORDS: Yield, tritordeum, wheat, triticale.

\section{INTRODUCTION}

Modern agronomic practices have contributed to the reduction of the number of cultivated species and their loss of genetic variability (Frankel and Hawkes, 1975). This reduction in genetic variability among cultivated species may interfere in the development superior materials. One alternative response to the process of genetic erosion is the development of new species by chromosomal duplication of hybrids between two species. This process has been used with the tribe Triticeae for the synthesis of triticale (XTriticosecale Wittmack), an amphiploid between durum wheat (Triticum turgidum conv. durum Desf. em. M.K.) and rye (Secale cereale L.), which is included in the cultivated plants (Varughese et al., 1987; Alvarez and Martin, 1994). Since the sucess of Kruse (1973) in obtaining hybrids between barley and wheat (Hordeum vulgare and Triticum aestivum, T. dicoccum and T. monococcum), many authors have attempted crosses between the two genera, but only few fertile hybrids (Martin and Chapman, 1977; Kimber and Sallee, 1979) were obtained by chromosome doubling with colchicine.

Two different amphiploids derived from the cross between a South American wild barley (Hordeum chilense Roem. et Schulz., genome $\mathrm{H}^{\mathrm{ch}} \mathrm{H}^{\mathrm{ch}}$ ) and wheat, named tritordeums, were obtained. Martin and Chapman (1977) synthesized an octoploid form with genome $\mathrm{AABBDDH}{ }^{\mathrm{ch}} \mathrm{H}^{\mathrm{ch}}$ and $2 \mathrm{n}=8 \mathrm{x}=48$ chromosomes from the cross between $H$. chilense and bread wheat ( $T$. aestivum L. em. Thell.). The other amphiploid is the hexaploid tritordeum with genome AABBH ${ }^{\text {ch }} \mathrm{H}^{\mathrm{ch}}$ and $2 \mathrm{n}=6 \mathrm{x}=42$ chromosomes $(H$. chilense $\mathrm{x}$ T. turgidum conv. durum), which was obtained for the first time in 1979 (Martin and Sanchez-Monge Laguna, 1982).

Since the beginning of the experiment, the hexaploid tritordeum showed promising characteristics as a new crop. Preliminary results indicated that the new species presents excellent grain morphology, high fertility, high protein content, a greater number of spikelet per ear and high tillering capacity (Martin and Cubero, 1981). Later studies (Cubero et al., 1986; Millan et al., 1988) have confirmed these positive results on yield and indicated a high tillering capacity and a high protein content in the grains. As far as its use for human consumption is concerned, Alvarez and Martin (1994) found that both hexa- and octoploid tritordeum exhibited breadmaking quality characteristics similar to those of bread wheat and very different from that of durum wheat. In regard to other nutritional characteristics, such as in vitro digestibility, neutral and acid detergent fiber, lignin, cellulose, hemicellulose, ether extract, $\mathrm{N}$ free extract and amino acid profile, tritordeum is similar to other cultivated cereals (Cubero et al., 1986).

The future use of tritordeum as a new cereal requires 
more information on its productive potential and on its performance compared to other winter cereals.

\section{MATERIAL AND METHODS}

A field experiment with complete randomized blocks and three replications was carried out on a typic xerofluvent soil (entisol) in Cordoba, Spain, 1996, during a normal growing season under temperatures ranging between 4.5 and $27.0{ }^{\circ} \mathrm{C}$. Two advanced tritordeum lines (HTC 486 and HTC 490) were compared with commercial varieties of wheat (Yecora and Cartaya), durum wheats (Mexa and Vitron) and triticales (Porsas, Daman, Montanchez and Trujillo). Grain yield (GY) was evaluated along with its number of ears/plot (EP), number of grains/ear (GE,) number of spikelets/ear (SE), number of grains/spikelet (GS), weight of a thousand grains (GW) and ear weight (EW).

Data for GE, SE, GS, GW and EW were obtained by sampling ten plants per plot. Analysis of variance were applied to the average of all samples from each plot, and correlations were calculated from multiobservation data from plot sampling.

Useful area per plot was $3 \mathrm{~m}^{2}$. To protect the experiment against birds, each plot consisted of three $2.5 \mathrm{~m}$ rows spaced at $0.4 \mathrm{~m}$ with 20 plants $/ \mathrm{m}$ at harvest. Plant density was 500 thousand plants/ha, and fertilization followed the recommendations for wheat cropping in the region.
Differences among treatments were detected using the linear model $\mathrm{Y}_{\mathrm{ij}}=\mu+\mathrm{T}_{\mathrm{i}}+\mathrm{R}_{\mathrm{j}}+\mathrm{e}_{\mathrm{ij}}$ where $\mathrm{Y}_{\mathrm{ij}}$ is the value of $i$-eth treatment in the $j$-eth replication, $\mu$ is the general mean, $T_{i}$ refers to the effect of $i$-eth treatment, $\mathrm{Rj}$ indicates the effect of $\mathrm{j}$-eth replication and $e_{i j}$ is the experimental error. Differences among botanic species and other varieties within the species were evaluated by the linear model $\mathrm{Y}_{\mathrm{ijk}}=\mu+\mathrm{S}_{\mathrm{i}}+\mathrm{G}_{\mathrm{j}(\mathrm{i})}$ $+R_{k}+e_{i j k}$ where $Y_{i j k}$ is the value of $j$-eth genotype or variety of the $i$-th species within the k-eth replication, $\mu$ refers to the general mean, $S_{i}$ indicates the effect of i-eth species, $G_{j(i)}$ is used to indicate the effect of $j$ eth genotype of variety within the i-eth species, $R_{k}$ refers to the effect of k-eth replication and $e_{i j k}$ is the experimental error.

\section{RESULTS AND DISCUSSION}

Table 1 shows the results of the analysis of variance regarding the global effect of the treatments. It also presents these effects in greater detail by partitioning the sums of the squares of the treatments. The $F$ values were highly significant for all the traits measured which led to the conclusion that there were consistent differences among the materials cultivated in Cordoba.

The results presented in Table 1 confirm the significant differences among the four cereals for all the yield components analyzed. Regarding the specific effect of each genotype, the differences

Table 1. Analysis of variance for grain yield and its components evaluated in hexaploid tritordeum, wheat, durum wheat and triticale cultivated in 1996 in Cordoba, Spain.

\begin{tabular}{|c|c|c|c|c|c|c|c|c|}
\hline \multirow[b]{2}{*}{ SV } & \multirow[b]{2}{*}{ DF } & \multicolumn{7}{|c|}{$\mathrm{MS}^{1 /}$} \\
\hline & & Ears/plot & Grains/ear & $\begin{array}{c}\text { Spikelets/ea } \\
\text { r }\end{array}$ & $\begin{array}{l}\text { Grains/ } \\
\text { spikelet }\end{array}$ & Ear weight & $\begin{array}{c}\text { Grain } \\
\text { weight }\end{array}$ & Grain yield \\
\hline Blocks & 2 & 8808.133 & 47.98 & 0.661 & 0.056 & 0.140 & 77.17 & 981895.789 \\
\hline Treatments & 9 & $138699.115^{4 /}$ & $456.069^{3 /}$ & $76.112^{4 /}$ & $0.764^{3 /}$ & $2.424^{4 /}$ & $324.230^{4 /}$ & $5153478.702^{4}$ \\
\hline $\begin{array}{l}\text { Among } \\
\text { species }\end{array}$ & 3 & $366481.84^{4 /}$ & $765.78^{3 /}$ & $193.48^{4 /}$ & $1.37^{3 /}$ & $5.46^{4 /}$ & $625.63^{4 /}$ & $7148339.80^{4 /}$ \\
\hline $\begin{array}{l}\text { Within } \\
\text { species }\end{array}$ & 6 & $(24807.75)$ & $(301.21)$ & (17.43) & $(0.46)$ & $(0.91)$ & $(173.53)$ & $(4156048.10)$ \\
\hline $\begin{array}{l}\text { Durum } \\
\text { wheat }\end{array}$ & 1 & 9680.17 & 762.03 & $35.82^{4 /}$ & 0.19 & $2.18^{4 /}$ & 34.05 & $5176993.78^{2 /}$ \\
\hline $\begin{array}{l}\text { Bread } \\
\text { wheat }\end{array}$ & 1 & 103753.50 & 341.26 & 0.75 & 0.52 & $1.41^{4 /}$ & 48.99 & $12451.82^{2 /}$ \\
\hline Triticale & 3 & 7784.22 & 207.94 & $12.80^{4 /}$ & 0.52 & $0.39^{4 /}$ & 296.07 & $4367943.04^{3 /}$ \\
\hline Tritordeum & 1 & 12060.17 & 80.16 & $29.61^{4 /}$ & 0.51 & $0.69^{4 /}$ & 69.94 & $6643014.20^{3 /}$ \\
\hline Error & 18 & 14281.726 & 124.768 & 1.389 & 0.175 & 0.030 & 69.781 & 705144.069 \\
\hline CV (\%) & & 15.96 & 15.40 & 4.60 & 13.95 & 12.84 & 22.76 & 12.97 \\
\hline
\end{tabular}

${ }^{1 /}$ Mean squares followed by ${ }^{2 /},{ }^{3 /} \mathrm{e}^{4 /}$ are significant at the $0.05,0.01$ and 0.001 probability levels, respectively, according to the $\mathrm{F}$ test. 
among varieties within each cultivated species mean were less expressive. Even so, differences were detected among ear weight and grain yield means for all and each one of the lines assessed. The number of spikelets per ear was also variable within each species, except in the case of hexaploid wheat. On the other hand, there was uniformity among each species for the number of ears per plot, number of grains per spikelet and weight of a thousand grains.

The tritordeum presented a satisfactory number of grains per ear and spikelets per ear reaching even surpassing other cereals for number of ears per plot (Table 2).

Considering that the sowing density was identical for all the materials, and that there were no stand failures, the greatest number of ears found in the plots occuppied by the tritordeum was a consequence of the greater profile given to the great number of ears per plant. This finding coincides with the great prolificity of tritordeum reported by Cubero et al. (1986), which is characteristic of the wild ancestor (H. chilense). Tritordeum also presented greater number of spikelets per ear, especially when compared to the hexaploid wheats.

The superiority of the tritordeum in ear number per plant and spikelets per ear indicates a good yield potential. However, this advantage over the other cereals was partially annulled by two factors which reduced the mean ear weight: high incidence of esterile spikelets, and low grain weight. The sum of these factors results in the superior productivity of the controls, especially because they presented heavier ears and a greater number of grains per spikelet (Table 2).

These correlations may bring useful data to the analysis of grain yield and its components. Results presented in Table 3 suggest that in general grain yield was associated to three basic traits: ear weight, number of grains per ear and grain density, the latter estimated by the weight of a thousand grains. Except in those plots occupied by tritordeum, ear weight was negatively correlated with the number of ears per plot, probably due to the competition among ears. Different from wheats in general, where ear weight was correlated with number of grains per ear, the number of grains per ear in the tritordeum did not seem to be the most limiting factor, but rather the weight of a thousand grains.

These results suggest new strategies for tritordeum breeding involving materials with greater grain weight and greater spikelet fertility. Under normal conditions, these characteristics would have positive effect on ear weight. Thus considering the natural prolificity of this new species, the selection of such materials may represent the starting point to obtain more productive tritordeums.

Table 2. Means ${ }^{1 /}$ of the traits evaluated in the cereals cultivated in 1996 in Cordoba, Spain.

\begin{tabular}{rlllllll}
\hline Genetic material & Ears/ plot & Grains/ear & $\begin{array}{c}\text { Spikelets/ } \\
\text { ear }\end{array}$ & $\begin{array}{c}\text { Grains/ } \\
\text { spikelet }\end{array}$ & $\begin{array}{c}\text { Ear } \\
\text { weight }^{2 /}\end{array}$ & $\begin{array}{c}\text { Grain } \\
\text { weight }^{3 /}\end{array}$ & Grain yield \\
\hline Durum wheat & $628.50 \mathrm{~B}$ & $63.84 \mathrm{~B}$ & $19.72 \mathrm{~B}$ & $2.88 \mathrm{~A}$ & $2.55 \mathrm{~B}$ & $39.94 \mathrm{~A}$ & $5273.00 \mathrm{C}$ \\
\cline { 2 - 7 } Mexa & $668.61 \mathrm{a}$ & $52.57 \mathrm{a}$ & $17.28 \mathrm{~b}$ & $2.37 \mathrm{a}$ & $1.95 \mathrm{~b}$ & $37.56 \mathrm{a}$ & $4344.00 \mathrm{~b}$ \\
Vitron & $588.26 \mathrm{a}$ & $75.11 \mathrm{a}$ & $22.17 \mathrm{a}$ & $3.39 \mathrm{a}$ & $3.16 \mathrm{a}$ & $42.32 \mathrm{a}$ & $6202.00 \mathrm{a}$ \\
\hline Bread wheat & $765.76 \mathrm{~B}$ & $74.24 \mathrm{AB}$ & $20.92 \mathrm{~B}$ & $3.56 \mathrm{~A}$ & $2.72 \mathrm{~B}$ & $36.51 \mathrm{~A}$ & $6732.50 \mathrm{AB}$ \\
\cline { 2 - 7 } Yecora & $897.29 \mathrm{a}$ & $66.69 \mathrm{a}$ & $20.57 \mathrm{a}$ & $3.26 \mathrm{a}$ & $2.24 \mathrm{~b}$ & $33.65 \mathrm{a}$ & $6687.00 \mathrm{a}$ \\
Cartaya & $634.22 \mathrm{a}$ & $81.78 \mathrm{a}$ & $21.28 \mathrm{a}$ & $3.85 \mathrm{a}$ & $3.21 \mathrm{a}$ & $39.36 \mathrm{a}$ & $6778.00 \mathrm{a}$ \\
\hline Tritordeum & $1114.50 \mathrm{~A}$ & $72.89 \mathrm{AB}$ & $30.58 \mathrm{~A}$ & $2.41 \mathrm{~B}$ & $1.56 \mathrm{C}$ & $21.58 \mathrm{~B}$ & $5696.50 \mathrm{BC}$ \\
\cline { 2 - 8 } HTC 486 & $1069.67 \mathrm{a}$ & $76.54 \mathrm{a}$ & $28.36 \mathrm{~b}$ & $2.70 \mathrm{a}$ & $1.90 \mathrm{a}$ & $24.99 \mathrm{a}$ & $6749.00 \mathrm{a}$ \\
HTC 490 & $1159.33 \mathrm{a}$ & $69.23 \mathrm{a}$ & $32.80 \mathrm{a}$ & $2.12 \mathrm{a}$ & $1.22 \mathrm{~b}$ & $18.16 \mathrm{a}$ & $4644.00 \mathrm{~b}$ \\
\hline Triticale & $617.14 \mathrm{~B}$ & $86.63 \mathrm{~A}$ & $28.39 \mathrm{~A}$ & $3.07 \mathrm{~A}$ & $3.55 \mathrm{~A}$ & $42.76 \mathrm{~A}$ & $7328.75 \mathrm{~A}$ \\
\cline { 2 - 8 } Porsas & $633.12 \mathrm{a}$ & $76.33 \mathrm{a}$ & $30.14 \mathrm{a}$ & $2.54 \mathrm{a}$ & $3.99 \mathrm{a}$ & $56.94 \mathrm{a}$ & $8389.00 \mathrm{a}$ \\
Daman & $626.48 \mathrm{a}$ & $96.56 \mathrm{a}$ & $27.84 \mathrm{~b}$ & $3.47 \mathrm{a}$ & $3.35 \mathrm{c}$ & $34.75 \mathrm{a}$ & $6993.00 \mathrm{abc}$ \\
Montanchez & $544.80 \mathrm{a}$ & $85.52 \mathrm{a}$ & $25.70 \mathrm{c}$ & $3.33 \mathrm{a}$ & $3.18 \mathrm{c}$ & $37.25 \mathrm{a}$ & $5769.00 \mathrm{~cd}$ \\
Trujillo & $664.17 \mathrm{a}$ & $88.10 \mathrm{a}$ & $29.87 \mathrm{ab}$ & $2.95 \mathrm{a}$ & $3.69 \mathrm{~b}$ & $42.10 \mathrm{a}$ & $8164.00 \mathrm{ab}$ \\
\hline
\end{tabular}

${ }^{1 /}$ Means of cultivated species and genotypes within each species followed by the same upper and lower case letter respectively, in each column, do not differ at 5\% probability, according to results of F-test and Duncan's multiple range test; ${ }^{2 /, 3 /}$ Ear weight (average weight of one ear) and grain weight (average weight of a thousand grains) are both expressed in grammes. 
Table 3. Simple linear correlation coefficients ${ }^{1 /}$ among yield traits evaluated in tritordeum, wheat, durum wheat and triticale cultivated in 1996 in Cordoba, Spain.

\begin{tabular}{|c|c|c|c|c|c|c|c|}
\hline \multicolumn{8}{|c|}{ Wheat } \\
\hline & $\begin{array}{l}\text { Grains } \\
\text { per ear }\end{array}$ & $\begin{array}{c}\text { Grain } \\
\text { weight }\end{array}$ & Ear weight & $\begin{array}{l}\text { Spikelets } \\
\text { per ear }\end{array}$ & $\begin{array}{l}\text { Grains per } \\
\text { spikelet }\end{array}$ & $\begin{array}{c}\text { Ears per } \\
\text { plot }\end{array}$ & $\begin{array}{l}\text { Grain } \\
\text { yield }\end{array}$ \\
\hline Grains/ear & - & 0.32 & $0.84^{2 /}$ & 0.18 & $0.91^{2 /}$ & -0.66 & 0.17 \\
\hline Grain weight & 0.32 & - & 0.78 & 0.40 & 0.17 & -0.68 & -0.09 \\
\hline Ear weight & $0.84^{2 /}$ & 0.78 & - & 0.33 & 0.70 & $-0.83^{2 /}$ & 0.06 \\
\hline Spikelets/ear & 0.18 & 0.40 & 0.33 & - & -0.25 & -0.38 & -0.18 \\
\hline Grains/spikelet & $0.91^{2 /}$ & 0.17 & 0.70 & -0.25 & - & -0.50 & 0.25 \\
\hline Ears/plot & -0.66 & -0.68 & $-0.83^{2 /}$ & -0.38 & -0.50 & - & 0.51 \\
\hline Grain yield & 0.17 & -0.09 & 0.06 & -0.18 & 0.25 & 0.51 & - \\
\hline \multicolumn{8}{|c|}{ Durum wheat } \\
\hline Grains/ear & - & 0.05 & $0.89^{2 /}$ & $0.91^{2 /}$ & $0.86^{2 /}$ & -0.58 & 0.67 \\
\hline Grain weight & 0.05 & - & 0.49 & 0.38 & -0.39 & 0.26 & 0.63 \\
\hline Ear weight & $0.89^{2 /}$ & 0.49 & - & $0.97^{3 /}$ & 0.56 & -0.40 & $0.87^{2}$ \\
\hline Spikelets/ear & $0.91^{2 /}$ & 0.38 & $0.97^{3 /}$ & - & 0.57 & -0.49 & 0.80 \\
\hline Grains/spikelet & $0.86^{2 /}$ & -0.39 & 0.56 & 0.57 & - & -0.62 & 0.31 \\
\hline Ears/plot & -0.58 & 0.26 & -0.40 & -0.49 & -0.62 & - & 0.10 \\
\hline Grain yield & 0.67 & 0.63 & $0.87^{2 /}$ & 0.80 & 0.31 & 0.10 & - \\
\hline \multicolumn{8}{|c|}{ Tritordeum } \\
\hline Grains/ear & - & -0.19 & 0.36 & -0.45 & $0.92^{3 /}$ & -0.14 & 0.39 \\
\hline Grain weight & -0.19 & - & $0.84^{2 /}$ & -0.51 & 0.09 & -0.52 & 0.56 \\
\hline Ear weight & 0.36 & $0.84^{2 /}$ & - & -0.73 & 0.59 & -0.54 & 0.77 \\
\hline Spikelets/ear & -0.45 & -0.51 & -0.73 & - & -0.77 & 0.41 & -0.50 \\
\hline Grains/spikelet & $0.92^{3 /}$ & 0.09 & 0.59 & -0.77 & - & -0.29 & 0.50 \\
\hline Ears/plot & -0.14 & -0.52 & -0.54 & 0.41 & -0.29 & - & 0.11 \\
\hline Grain yield & 0.39 & 0.56 & 0.77 & -0.50 & 0.50 & 0.12 & - \\
\hline \multicolumn{8}{|c|}{ Triticale } \\
\hline Grains/ear & - & $-0.91^{3 /}$ & -0.53 & -0.18 & $0.91^{3 /}$ & 0.22 & -0.14 \\
\hline Grain weight & $-0.91^{3 /}$ & - & $0.80^{3 /}$ & 0.49 & $-0.95^{3 /}$ & -0.05 & 0.41 \\
\hline Ear weight & -0.53 & $0.80^{3 /}$ & - & $0.84^{3 /}$ & $-0.79^{3 /}$ & 0.27 & $0.75^{3 /}$ \\
\hline Spikelets/ear & -0.18 & 0.49 & $0.84^{3 /}$ & - & $-0.58^{2 /}$ & $0.63^{2 /}$ & $0.90^{3 /}$ \\
\hline Grains/spikelet & $0.91^{3 /}$ & $-0.95^{3 /}$ & $-0.79^{3 /}$ & $-0.58^{2 /}$ & - & -0.10 & -0.51 \\
\hline Ears/plot & 0.22 & -0.05 & 0.27 & $0.63^{2 /}$ & -0.10 & - & $0.84^{3 /}$ \\
\hline Grain yield & -0.14 & 0.41 & $0.75^{3 /}$ & $0.90^{3 /}$ & -0.51 & $0.84^{3 /}$ & - \\
\hline \multicolumn{8}{|c|}{ General (all the species) } \\
\hline Grains/ear & - & -0.19 & $0.48^{3 /}$ & $0.38^{2 /}$ & $0.54^{3 /}$ & -0.24 & $0.45^{2}$ \\
\hline Grain weight & -0.19 & - & $0.75^{3 /}$ & -0.12 & -0.07 & $-0.61^{3 /}$ & $0.44^{2}$ \\
\hline Ear weight & $0.48^{3 /}$ & $0.75^{3 /}$ & - & 0.10 & 0.33 & $-0.75^{3 /}$ & $0.68^{3 /}$ \\
\hline Spikelets/ear & $0.38^{2 /}$ & -0.12 & 0.10 & - & $-0.56^{3 /}$ & 0.34 & 0.34 \\
\hline Grains/spikelet & $0.54^{3 /}$ & -0.07 & 0.33 & $-0.56^{3 /}$ & - & $-0.50^{3 /}$ & 0.08 \\
\hline Ears/plot & -0.24 & $-0.61^{3 /}$ & $-0.75^{3 /}$ & 0.34 & $-0.50^{3 /}$ & - & -0.07 \\
\hline Grain yield & $0.45^{2 /}$ & $0.44^{2 /}$ & $0.68^{3 /}$ & 0.34 & 0.08 & -0.07 & - \\
\hline
\end{tabular}

${ }^{1 /}$ Correlation coefficients followed by ${ }^{2 /}$ and $^{3 /}$ are statistically significant at 0.05 and 0.01 levels of probability, respectively.

\section{CONCLUSIONS}

Considering the fairly reasonably yield values compared with the commercial controls, and taking into consideration that it is a new species with little breeding yet, the results indicates a great potential in the tritordeum to develop highly productive varieties. Selection and evaluation of new tritordeums, accompanied by monitoring of the breadmaking quality, may be fundamental for a medium or long term cultivation of this new species.

\section{RESUMO}

Avaliação Preliminar dos Componentes do Rendimento de Grãos em Tritórdeo Hexaplóide

A duplicação cromossômica dos híbridos entre Hordeum chilense e Triticum turgidum conv. durum originou um novo cereal com características favoráveis ao plantio: o tritórdeo hexaplóide ( $X$ Tritordeum Ascherson et Graebner). Com o objetivo 
de obter maiores informações sobre o potencial produtivo do tritórdeo para o rendimento de grãos e seus componentes, foi instalado em $1996 \mathrm{em}$ Córdoba, Espanha, um experimento de campo com 3 repetições. O desempenho de dois tritórdeos avançados foi comparado com o rendimento de variedades comerciais de trigo, trigo duro e triticale. O conjunto de resultados indicou um grande potencial do tritórdeo para o desenvolvimento de variedades altamente produtivas, especialmente por se tratar de uma espécie nova e ainda pouco melhorada.

\section{REFERENCES}

Alvarez, J.B. and Martin, L.M. 1994. The amphiploid Hordeum chilense $\mathrm{x}$ Triticum aestivum. Evaluation of its grain, flour and dough characteristics and comparison with those of other related cereals. Cereal Res. Comm. 22:49-56.

Cubero, J.I.; Martin, A.; Millan, T.; Cabrera, A. and De Haro, A. 1986. Tritordeum: a new alloploid of potential importance as a protein source crop. Crop Sci. 26:1186-1190.

Frankel, O.H. and Hawkes, J.G. 1975. Genetic resources - the past ten years and the next. p.1-11. In: Frankel, O.H. and Hawkes, J.G. (Eds.). Crop genetic resources for today and tomorrow. Cambridge University Press, Cambridge.

Kimber, G. and Sallee, P.J. 1979. A trigeneric hybrid in the Triticeae. Cereal Res. Comm. 7:5-9.

Kruse, A. 1973. Hordeum x Triticum hybrids. Hereditas. 73:157-161.

Martin, A. and Chapman, V. 1977. A hybrid between Hordeum chilense and Triticum aestivum. Cereal Res. Comm. 5:365-368.

Martin, A. and Cubero, J.I. 1981. The use of Hordeum chilense in cereal breeding. Cereal Res. Comm. 9:317323.

Martin, A. and Sanchez-Monge Laguna, E. 1982. Cytology and morphology of the amphiploid Hordeum chilense $\mathrm{x}$ Triticum turgidum conv. durum. Euphytica 31:261- 267.

Millan, T.; Martin, A. and De Haro, A. 1988. Field trial of tritordeum. Cereal Res. Comm. 16:31-38.

Varughese, G.; Baker, T. and Saari, E. 1987. Triticale. CIMMYT, México.

Received: September 17, 2001; Accepted: August 08, 2002. 
